\title{
MODELING OF FORWARDER PRODUCTIVITY AND COSTS IN THINNED PINE STANDS
}

\author{
Carla Krulikowski Rodrigues ${ }^{1 *}$, Eduardo da Silva Lopes ${ }^{1}$, Afonso Figueiredo Filho ${ }^{1}$, Matheus Kaminski Cândido \\ da Silva ${ }^{1}$ \\ 1* Universidade Estadual do Centro-Oeste, Departamento de Engenharia Florestal, Irati, Paraná, Brasil - carlakr@gmail.com; \\ eslopes@unicentro.br; afigfilho@gmail.com; matheuskcs@gmail.com \\ Recebido para publicação: 06/11/2017 - Aceito para publicação: 18/12/2017
}

\begin{abstract}
The aim of this study was to assess the influence of some operational variables on the forwarder productivity and production cost in thinned Pinus taeda L. stands by means of mathematical modeling. This study was carried out in a forest company located at Quedas do Iguaçu, state of Paraná, Brazil. Two stands at 9 and 10 years old from sites with high productivity and similar soil and relief features were studied. A time-motion study was applied to determine the operational cycle time, operational efficiency, productivity, and production costs. By means of mathematical modeling, we verified the influence of the variables: age of stand; cycle time; load volume; and extraction distance on the forwarder productivity and production costs. Models were fitted for estimating the forwarder productivity using cycle time, load volume, and extraction distance. Thus, we obtained the determination adjusted coefficients of 0.88 and 0.94 , with an estimate standard error between $6.9 \%$ and $13.5 \%$. Models for estimating production cost through the load volume variable presented a determination coefficient of 0.64 and 0.86 , with an estimate standard error of $23.1 \%$ and $26.7 \%$. Such results have shown the possibility of using mathematical models to estimate the performance of forest machines as a tool for planning the timber harvesting operations.

Keywords: Timber extraction, operational variables, harvesting planning.
\end{abstract}

\section{Resumo}

Modelagem da produtividade e custos do forwarder no desbaste em povoamentos pinus. Objetivou-se neste estudo avaliar algumas variáveis de influência na produtividade e custos de um forwarder em povoamentos de Pinus taeda L. submetidos ao desbaste por meio de modelagem matemática. O estudo foi realizado em uma empresa florestal localizada no município de Quedas do Iguaçu, estado do Paraná. Foram estudados dois povoamentos com idades de 9 e 10 anos, localizados em sítios de alta produtividade e semelhantes entre si em relação ao tipo de solo e relevo. Foi realizado um estudo de tempos e movimentos, determinando os tempos dos ciclos operacionais, a eficiência operacional, a produtividade e os custos de produção. Foram verificadas a influência das variáveis: idade do povoamento; tempo do ciclo; volume de carga; e distância de extração na produtividade e custos de produção do forwarder por meio de modelagem matemática. Em povoamentos com 9 e 10 anos, os modelos ajustados para a estimativa do forwarder por meio das variáveis tempo do ciclo, volume de carga e distância de extração apresentaram coeficientes de determinação ajustados de 0,88 e 0,94, com um erro padrão de estimativa de $6,9 \%$ e $13,5 \%$. Os modelos para a estimativa dos custos de produção por meio da variável volume de carga apresentaram um coeficiente de determinação de 0,64 e 0,86 , com erro padrão de estimativa de $23,1 \%$ e $26,7 \%$. Tais resultados mostraram a possibilidade do uso de modelos matemáticos para a estimativa do rendimento da máquina, podendo ser utilizados como ferramenta no planejamento das operações de colheita da madeira.

Palavras-chave: Extração florestal,variáveis operacionais, planejamento.

\section{INTRODUCTION}

As a silvicultural practice, thinning is the partial harvesting of trees in forest stands from spatial criteria, in order to provide growth continuity of tree remnants by means of reducing intraspecific competitiveness for environmental elements, such as water, light, and nutrients. Generally, thinning is carried out from below, by removing some lower trees, so that the trees with superior features in vitality, stem quality and growth remain, and the production of wood of the best quality increases (SCHNEIDER; SCHNEIDER, 2008; CARNEIRO et al., 2012).

However, the removal of trees from stands through thinning is a complex and costly process due to the low mobility of machines within the stand, low individual volume, quantity of removed trees, and necessity to produce several assortments. In addition, mechanized operations of forest harvesting in stands under thinning result

FLORESTA, Curitiba, PR, v. 48, n. 2, p. 285-292, abr/jun. 2018.

Rodrigues. C. K. et.al.

ISSN eletrônico 1982-4688

DOI: $10.5380 /$ rf.v48 i2.56195 
in low operational productivity and high production costs, as a consequence of the influence of variables related to the characteristics of the stand, terrain slope, and available machines, such as species, spacing, individual tree stem volume, assortments, declivity, extraction distance, and operator's experience and ability (MALINOVISKI et al., 2006; NURMINEN et al., 2006; SPINELLI; NATI, 2009; NUUTINEN et al., 2010).

Forwarder is the most common machine in forest extraction. It is a self-loading and articulated forest tractor, formed by a hydraulic crane and a loading platform, tire wheels or mats, and four, six or eigth wheel drive (WD). It is also responsible for timber extraction from the interior of stands (SEIXAS et al., 2014). This machine can have its operating income affected by several variables. When considered in the planning of harvesting operations, it can optimize activities, maximizethe machine productivity, and reduce the production costs.

Research projects that aim to determine influence variables on the productivity and production costs of a forwarder have already been carried out in clear-cutting situations. Some variables that stand out are: dimensions of the logs, the greater dimension the more optimized use of the load compartment (OLIVEIRA et al., 2009); load volume, which can be expanded as long as it respects the weight limit recommended by the manufacturer, so that its use can be optimized (CARMO et al., 2015); and extraction distance, which provides a decrease in productivity and an increase in costs as the distance increases (LEITE et al., 2014). These variables can be used in the mathematical modeling of productivity and costs, aiming to understand how the operational conditions and characteristics of the stands influence in forest extraction. Therefore, it would be possible to estimate the yields of the machine and get lower costs, regularize the production and obtain better work.

Brazil lacks studies regarding the influence of variables on the performance of machines in stands under the first thinning, even though this silvicultural practice is commonly applied in Pinus spp. stands in the Southern region. The absence of specific studies leads to modify the planning of timber harvesting, since data are obtained in different realities, such as clear-cutting operation. Therefore, it highlights the need of research under specific conditions. Thus, the aim of this study was to verify the influence of some operational variables on the forwarder productivity and production costs in thinned Pinus taeda L. stands by means of mathematical modeling, in order to contribute to forest operation and harvesting planning.

\section{MATERIALS AND METHODS}

The study was carried out in a forestry company located at Quedas do Iguaçu, state of Paraná, Brazil, between the coordinates $25^{\circ} 26^{\prime} 27^{\prime \prime} \mathrm{S}$ and 52 $2^{\circ} 55^{\prime} 17^{\prime \prime} \mathrm{W}$. Data were collected in Pinus taeda $\mathrm{L}$. stands, submitted to first commercial thinning. The climate of the region is classified as humid subtropical (Cfa Köppen), average temperature below $18{ }^{\circ} \mathrm{C}$ in the coldest month and above $22{ }^{\circ} \mathrm{C}$ in the hottest month, hot summer, occasional frost, rainfall concentrated in the summer months, and average annual rainfall of 1,779 mm (CAVIGLIONE et al., 2000). Soil was classified as Lithic Ustorthent, and relief was describe as smoothly undulated, with average slope of $8 \%$.

Two Pinus taeda L. stands at 9 and 10 years old from sites with high productivity and similar soil and relief features were studied. These stands were planted at initial density of 1,667 trees per hectare, with pruning at 4 years old, and 1,437 and 1,417 trees per hectare at 9 and 10 years old. They had average height of 15.2 and $15.6 \mathrm{~m}$, average diameter of 19,6 and $19,1 \mathrm{~cm}$, and individual average volume of 0.225 and $0.215 \mathrm{~m}^{3}$, respectively.

Thinning was classified as mixed, characterized by the systematic cut of the fifth line, which removed $20 \%$ of the trees and enabled the operating tracks of the machines by the maximum reach of the harvester crane. Posteriorly, $30 \%$ of the trees with inferior quality were removed in two lines adjacent to the traffic trails of the machines. This provided the total removal of $50 \%$ of the trees, which represented $35 \%$ of the initial basal area.

During the thinning, two assortments of logs were produced and classified as saw wood (diameter between 15.0 and $35.5 \mathrm{~cm}$ and length of $3.60 \mathrm{~m}$ for sawmill) and firewood (diameter between 3.5 and $15.0 \mathrm{~cm}$ and length of $3.05 \mathrm{~m}$ for energy). During the extraction of the wood, the forwarder intercalated the trips in two extraction procedures. The first one extracted only the firewood (energy wood), and the second extracted the firewood and the saw wood (sawmill wood), according to the procedure adopted by the company.

The forwarder studied had a motor with nominal power of $212 \mathrm{HP}$; operating weight of 18,900 kg; gross load of 15,000 kg; hour meter with 5,540 hours; $8 \mathrm{WD}$; reach of 7,8 m; grab with a weight of $240 \mathrm{~kg}$; and a floor area of $0.28 \mathrm{~m}^{2}$.

Initially, we performed a time-motion study of the forwarder in timber extraction using the continuous timing method. The minimum number of operational required cycles (n) was obtained in a pilot study (1), according to the methodology proposed by Barnes (1977).

$$
\mathrm{n} \geq \frac{\mathrm{t}^{2} \cdot C V^{2}}{\mathrm{LE}^{2}}
$$


In which: $\mathrm{n}=$ minimum number of required cycles; $\mathrm{t}=$ value at $5 \%$ of significance; $\mathrm{CV}=$ coefficient of variation in percentage; and $\mathrm{LE}=$ error limit of $12 \%$.

The forwarder operational cycle was divided into the partial elements: i) Empty travel (ET), consisted of the time of machine displacements from the edge of the stand to the first log pile loaded inside the stand; ii) Loading (LO), referred to the time of crane movement for loading the logs and displacements among the log piles; iii) Loaded travel (LT), consisted of the time of machine movement inside the stand after the load was finished; iv) Unloading (UN), referred to the time of crane movement for unloading the logs, including the maneuvers necessary for the beginning of the next operational cycle; and v) Interruptions (IN), consisted of the time in which the machine did not perform the activities previously mentioned.

We determined the operational efficiency and the machine productivity for timber extraction in the stands at 9 and 10 years old. Thus, the operational efficiency $(\mathrm{E})$, defined as the percentage of the worked time in relationship to the programmed one, was obtained by the formula (2).

$$
\mathrm{OE}=\frac{\mathrm{ET}}{\mathrm{PT}} .100
$$

In which: $\mathrm{OE}=$ operating efficiency $(\%)$; ET = effective working time (hours); and PT = programmed working time (hours).

Forwarder productivity was obtained by the load volume ratio $\left(\mathrm{m}^{3}\right)$ and consumed time in the operating cycle (hours). For this purpose, the number of logs loaded in each operational cycle of the unloading step (Nt), whose value was multiplied by the average volume of scaling logs $(\mathrm{Vt})$ in the firewood and saw wood assortments, was counted and divided by the time of the cycle in hours (3).

$$
\mathrm{PR}=\frac{\mathrm{AV} \cdot \mathrm{NL}}{\mathrm{eh}}
$$

In which: $\mathrm{PR}=$ forwarder productivity $\left(\mathrm{m}^{3} \mathrm{eh}^{-1}\right) ; \mathrm{AV}=$ average log volume $\left(\mathrm{m}^{3}\right) ; \mathrm{NL}=$ number of logs extracted in each operational cycle; and eh = effective working hours (hours).

Operational and production costs were determined considering the operational cost, the sum of the fixed variables, operational and administrative costs, represented by the effective working hours: i) Fixed costs (depreciation, interest, and insurance) were estimated by the methodology proposed by Miyata (1980); ii) Variable costs (fuels, hydraulic oil, lubricants and greases, tires, maintenance, and repairs); iii) Operational staff (salary and social charges), provided by the company and obtained in the field; and iv) Administrative costs, obtained from the direct machine costs.

The production cost was calculated by the ratio of operating cost and forwarder productivity (4).

$$
\mathrm{PC}=\frac{\mathrm{OC}}{\mathrm{PR}}
$$

In which: $\mathrm{PC}=$ production cost $\left(\mathrm{R} \$ \mathrm{~m}^{-3}\right) ; \mathrm{OC}=$ operational cost $\left(\mathrm{R} \$ \mathrm{eh}^{-1}\right)$; and $\mathrm{PR}=$ forwarder productivity $\left(\mathrm{m}^{3} \mathrm{eh}^{-1}\right)$.

Time data of the forwarder operational cycle at different ages of the stands (treatment) were assessed using the Kolmogorov-Smirnov's normality test at $5 \%$ of error probability. Data transformations did not provide normal distributions. Therefore, the mean values were compared by the Wilcoxon-Mann-Whitney's test, considered as a non-parametric method applied to compare two independent samples ( 9 and 10 years).

Then, a multiple linear regression analysis was performed to verify the relation between the dependent variables: forwarder productivity (PR) and production costs (PC); and among the independent variables that influence the operational capacity of the forwarder: age of stands (A), operational cycle time (CT), load volume (LV), and extraction distance (ED).

FLORESTA, Curitiba, PR, v. 48, n. 2, p. 285-292, abr/jun. 2018.

Rodrigues. C. K. et.al.

ISSN eletrônico 1982-4688

DOI: $10.5380 /$ rf.v48 i 2.56195 
Initially, we verified the data normality and the variance homogeneity of the forwarder productivity and production cost. Then, a simple linear correlation matrix (Spearman) of the potential variables (A, CT, LV, and ED) was carried out in order to select those with the highest correlations, according to Callegari-Jacques (2003). They were classified in: weak linear correlation (up to 0.30 ); moderate (0.31 to 0.60 ); strong (0.61 to 0.90$)$; and very strong (above 0.90 ).

In order to fit the models, the independent variables were selected by stepwise method using the Action Stat supplement in Microsoft Excel. The fitted models were presented with the following statistics: adjusted coefficient of determination ( $\mathrm{R}^{2} \mathrm{aj}$ ); standard error of the estimate in percentage (Syx\%); F value; and significance of the regression coefficients ( $\beta \mathrm{i}$ ). In addition, we applied the Graybill's identity test (GRAYBILL, 1976) to verify the possibility of grouping the data through the age variable and using a reduced model. Based on the possibility of estimating the forwarder productivity in Pinus taeda stands at 9 and 10 years old, the estimated productivity variation was plotted in a figure by means of cycle time, load volume, and extraction distance variables.

\section{RESULTS}

In the time-motion study, 30 and 53 forwarder operational cycles were measured for the stands at 9 and 10 years old, respectively, considering the error limit of $12 \%$. The average time of the forwarder operational cycles in Pinus taeda stands under thinning are presented in Table 1. Loading consumed the most operational cycle time (53.2\% and $60.3 \%$ ), followed by unloading $(25.1 \%$ and $25.5 \%)$, totalizing $78.3 \%$ and $85.8 \%$ of the time operational cycle at 9 and 10 years old, respectively.

Table 1. Average times of the forwarder operational cycle in Pinus taeda stands at 9 and 10 years old. Tabela 1. Tempos médios do ciclo operacional do forwarder em povoamentos de Pinus taeda de 9 e 10 anos.

\begin{tabular}{cccc}
\hline & \multicolumn{3}{c}{ Age of stands (Years) } \\
\cline { 2 - 3 } Cycle elements & $\mathbf{9}$ & $\mathbf{1 0}$ & p-value \\
\cline { 2 - 3 } & Times & Times & 0,0001 \\
Empty travel (s) & $138^{* *}$ & $81^{* *}$ & 0,7633 \\
Loading (s) & $526^{\mathrm{ns}}$ & $544^{\mathrm{ns}}$ & 0,1125 \\
Loaded travel (s) & $77^{\mathrm{ns}}$ & $47^{\mathrm{ns}}$ & 0,9883 \\
Unloading firewood (s) & $156^{\mathrm{ns}}$ & $156^{\mathrm{ns}}$ & 0,3867 \\
\hline Unloading saw wood (s) & $92^{\text {ns }}$ & $74^{\mathrm{ns}}$ & $\mathbf{0 , 3 0 8 9}$ \\
\hline Total time cycle (s) & $\mathbf{9 8 9}^{\text {ns }}$ & $\mathbf{9 0 2}^{\text {ns }}$ & \\
\hline
\end{tabular}

In which: $\mathrm{s}=$ seconds; $* *=1 \%$ of significance $(\mathrm{p}<0.01)$; and $\mathrm{ns}=$ non-significance $(\mathrm{p} \geq 0.05)$.

Loading firewood consumed $15.8 \%$ and $17.3 \%$ of the total cycle time at 9 and 10 years old, respectively. It was higher than unloading saw wood, which consumed $9.3 \%$ and $8.2 \%$ of the total cycle time. These results occur due to the less amount of crane movement for unloading saw wood, due to its volume. Thus, it reduced the cycle time when it presented this assortment in the loading compartment. Consequently, it resulted in a higher productivity of the machine.

Forwarder had average operational efficiency of $84 \%$ and average productivity of 37.0 and $37.6 \mathrm{~m}^{3} \mathrm{eh}^{-1}$ in stands at 9 and 10 years old, respectively. The operational cost per hour worked was $\mathrm{R} \$ 180.93$ and the average production costs were $\mathrm{R} \$ 4.89$ and $\mathrm{R} \$ 4.81 \mathrm{~m}^{-3}$ at 9 and 10 years, respectively.

Table 2 presents the linear correlation matrix considering the productivity (PR) and the production cost (PC) of the forwarder in relation to the variables: age of stand (A), operational cycle time (CT), load volume (LV), and extraction distance (ED). Load volume showed a strong correlation with the forwarder productivity $(0.74)$ and the production costs $(-0.71)$, whereas the operational cycle time and extraction distance variables had a weak correlation $(<0.30)$. However, the age of stands variable did not present correlation with the other variables, being 0.02 with the productivity and 0.04 with the production costs. Consequently, this variable was not included in the fitted models. 
Table 2. Simple Linear Correlation Matrix (Spearman) of the forwarder productivity and production cost with the potential variables (A, CT, LV, ED).

Tabela 2. Matriz de Correlação Linear Simples (Spearman) entre a produtividade e custos de produção do forwarder com as variáveis potenciais (A, CT, LV, ED).

\begin{tabular}{|c|c|c|c|c|c|c|}
\hline Variables & PR & PC & $\mathbf{A}$ & CT & LV & ED \\
\hline PR & 1,00 & & & & & \\
\hline PC & $-1,00^{* *}$ & 1,00 & & & & \\
\hline $\mathbf{A}$ & $-0,01^{\mathrm{ns}}$ & $0,01^{\mathrm{ns}}$ & 1,00 & & & \\
\hline CT & $0,36^{* *}$ & $-0,36^{* *}$ & $0,01^{\mathrm{ns}}$ & 1,00 & & \\
\hline $\mathbf{L V}$ & $0,77^{* *}$ & $-0,77^{* *}$ & $0,06^{\mathrm{ns}}$ & $0,83^{* *}$ & 1,00 & \\
\hline ED & $0,22^{*}$ & $-0,22^{*}$ & $0,12^{\text {ns }}$ & $0,74^{* *}$ & $0,62^{* *}$ & 1,00 \\
\hline
\end{tabular}

CT, LV and ED correlations with forwarder productivity were positive, whereas they were negative with production cost. Forwarder productivity and production cost showed similar behavior with the assessed variables. The highest load volumes and the shortest operational cycle time and extraction distance increased the forwarder productivity and decreased the production cost.

Variables that showed a statistical significance of correlation with forwarder productivity and production cost were used to obtain some equations (Table 3). For the estimate of forwarder productivity, the models showed determination adjusted coefficients from 0.88 to 0.94 , with estimate standard error of $6.87 \%$ and $13.51 \%$ for 9 and 10 years old stands, respectively. In the production cost models, the determination adjusted coefficients were 0.64 and 0.86; however, the values of estimate standard error were high $(23.09 \%$ and $26.74 \%)$. Thus, it decreased the applicability of these models, since the production cost is a very sensitive variable for planning timber harvesting operations.

Table 3. Coefficients and statistics of the models to estimate the forwarder productivity and production cost in thinning operations in Pinus taeda stands at 9 and 10 years old.

Tabela 3. Coeficientes e estatísticas dos modelos para estimativa da produtividade e custo de produção do forwarder nas operações de desbaste em povoamentos de Pinus taeda nas idades de 9 e 10 anos.

\begin{tabular}{|c|c|c|c|c|c|}
\hline \multicolumn{6}{|c|}{ Productivity $\left(\mathrm{m}^{3} \mathrm{~h}^{-1}\right)$} \\
\hline Age (Years) & Equation & $\mathbf{R}^{2} \mathbf{a j}$ & Syx\% & $\mathbf{F}$ & IM \\
\hline 9 & $\mathrm{PR}=27,875^{*}-79,992^{*} . \mathrm{CT}+3,242^{*} \cdot \mathrm{LV}-0,035^{*} \cdot \mathrm{ED}$ & 0,943 & 6,87 & 100 & - \\
\hline 10 & $\mathrm{PR}=37,625^{*}-152,088^{*} \cdot \mathrm{CT}+4,021^{*} \cdot \mathrm{LV}-0,015^{*} \cdot \mathrm{ED}$ & 0,879 & 13,51 & 121 & - \\
\hline \multicolumn{6}{|c|}{ Production cost $\left(R \$ ~ m^{-3}\right)$} \\
\hline Age (Years) & Equation & $\mathbf{R}^{2} \mathbf{a j}$ & Syx\% & $\mathbf{F}$ & IM \\
\hline 9 & $\ln (\mathrm{PC})=2,606^{*}-0,400^{*} \cdot \ln (\mathrm{LV})$ & 0,64 & 23,09 & 30 & 1,02 \\
\hline 10 & $\ln (\mathrm{PC})=2,401^{*}-0,465^{*} \cdot \ln (\mathrm{LV})$ & 0,86 & 26,74 & 82 & 1,03 \\
\hline
\end{tabular}

In which: $\mathrm{PR}=$ productivity $\left(\mathrm{m}^{3} \mathrm{eh}^{-1}\right) ; \mathrm{PC}=$ production cost $\left(\mathrm{R} \$ \mathrm{~m}^{-3}\right) ; \mathrm{CT}=$ cycle time (hours); $\mathrm{LV}=$ load volume $\left(\mathrm{m}^{3}\right) ; \mathrm{ED}=\mathrm{extraction}$ distance $(\mathrm{m}) ; \mathrm{R}^{2} \mathrm{aj}=$ adjusted coefficient of determination; Syx $\%=$ standard error of estimate in percentage; $\mathrm{F}=$ statistics $\mathrm{F} ; \mathrm{IM}=\mathrm{Meyer}$ index; and $*=$ significance of regression coefficients at $5 \%$ of significance $(\mathrm{p}<0.05)$.

Table 4 shows the results of the identity test applied to the models for estimating forwarder productivity and production cost, grouped by the age of stands. Although the ages were close, it was not possible to group the data. Thus, it was necessary to carry out the estimates using a model for each age, since the relation among dependent and independent variables did not present the same behavior in the interactions. 
Table 4. Identity test applied to models for estimating the forwarder productivity and production cost, grouped by the age of stand.

Tabela 4. Teste de identidade aplicado aos modelos para a estimativa de produtividade e custos de produção agrupados pela variável idade dos povoamentos.

\begin{tabular}{cccccc}
\hline Model & QMdifference & QM $_{\text {residue }}$ & F & $\mathbf{F}_{\boldsymbol{\alpha}}$ & Significance \\
\hline PR & 27,231 & 21,360 & 1,275 & 0,176 & Yes \\
CP & 0,797 & 0,055 & 14,413 & 0,051 & Yes \\
\hline
\end{tabular}

In which: $\mathrm{PR}=$ productivity; $\mathrm{CP}=$ cost of production; $\mathrm{QM}=$ average square; $\mathrm{F}=$ statistics $\mathrm{F} ; \mathrm{F} \alpha=$ critical $\mathrm{F}$ value; and Significance = statistical difference at $5 \%$ of significance.

Figure 1 shows the relation among the forwarder productivity and the operational cycle time, load volume, and extraction distance variables in Pinus taeda stands at 9 and 10 years old. We used the average distance of $100 \mathrm{~m}$ since this variable had few influence on the machine productivity, due to its low correlation with the dependent variable.

The weak correlation of the extraction distance with the forwarder productivity in stands under thinning differs from clear-cut operations, which reduce its productivity over the longer distances. In the present study, the forwarder only extracted firewood under lower extraction distances, since it was possible for the machine to complete its load capacity without large displacements inside the stands. However, when two assortments were extracted (firewood and saw wood) in a single operational cycle, the machine had to move larger distances to complete the load, providing a higher load volume in the operational cycle. Consequently, the difference in load volume was equilibrated by the time consumed with empty and loaded travels, due to the longer distance crossed, as well as the presence of saw wood, which reduced the time consumed in the unloading activity.
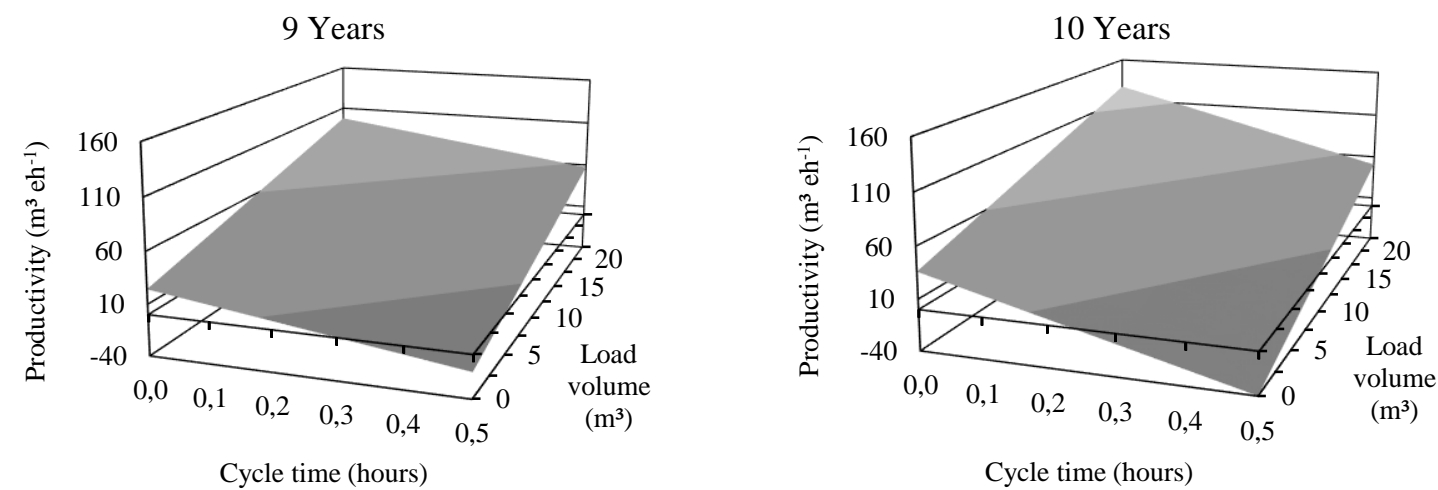

Figure 1. Variation of the estimated forwarder productivity in Pinus taeda stands under thinning at 9 and 10 years old, according to the cycle time and load volume, under the average extraction distance of $100 \mathrm{~m}$.

Figura 1. Variação da produtividade estimada do forwarder em povoamentos de Pinus taeda submetidos ao desbaste aos 9 e 10 anos, em função do tempo do ciclo operacional, volume de carga, na distância de extração média de $100 \mathrm{~m}$.

\section{DISCUSSION}

Forwarder operational cycle analysis showed that most of the time was consumed in a passive way, as the machine was loading and unloading.The same occurs in forest stands submitted to a clear-cut regime. In order to increase the forwarder productivity, the results showed that it is necessary to adopt procedures to optimize the operation through the quality of log piles, use of crane with long reach, and extraction of the assortments separately (LOPES et al., 2010; LOPES et al., 2016; MAZÃO et al., 2017).

Empty and loaded travel stages consumed the shortest operational cycle times, which evidences that the extraction distances presented low correlation with forwarder productivity. We noticed a tendency to increase the forwarder productivity at the largest extraction distances, due to the presence of saw wood associated with firewood. This was also verified by Lopes et al. (2016). According to the authors, the forwarder productivity increased in the distance class higher than $150 \mathrm{~m}$ for the associated extraction of firewood and saw wood assortments.

In this study, the load volume was the main variable that influenced on the forwarder productivity, affecting the production cost. Therefore, it is possible to optimize the thinning extraction operation and increase the forwarder productivity through the expansion of the loading compartment. In the time-motion study, the 
average load weight was $9,000 \mathrm{~kg}( \pm 5,300 \mathrm{~kg})$, and the lowest values were found in the travels with only firewood, as the capacity of the load compartment was $15,000 \mathrm{~kg}$. For Carmo et al. (2015), it is possible to maximize the forwarder productivity and consequently reduce production costs by increasing the height of the stoves. Thus, a largest load box would be obtained, since the wood density and the volume transported do not compromise the machine stability.

The age of stands variable did not correlate with the forwarder productivity and production cost, and was excluded from the fitted models by the stepwise process. Although the ages were close, the identity test model did not provide the possibility of grouping the data according to the age of the stands, requiring a model for each one when estimating the productivity of the machine.

Thus, models for estimating productivity through cycle time, load volume, and extraction distance, as well as production cost by load volume, showed potential to be used as a tool for planning timber harvesting. Also, we can estimate the machine operating income and verify the influence of the variables, such as the forwarder load capacity, aiming to optimize the harvesting operations and obtain higher productivity and lower production cost.

\section{CONCLUSIONS}

- Loading and unloading operations consume the longest forwarder operating cycle and are not affected by the 9 and 10 years old stands.

- Timber extraction of the same assortment can optimize loading and unloading times; thus increasing productivity and reducing production cost.

- Load volume is the variable with the greatest influence on the forwarder productivity. The use of a forwarder with higher load capacity on the timber extraction in stands under first thinning is recommended.

- For the fitted models, load volume, cycle time, and extraction distance are the best variables for estimating the forwarder productivity, whereas load volume is recommended for predicting production cost.

- Fitted equations can be used to estimate the forwarder productivity as a tool for planning forest harvesting and predicting the machine performance.

\section{ACKNOWLEDGMENTS}

The authors thank the National Council for Scientific and Technological Development $(\mathrm{CNPq})$ for financing this research, the Coordination for the Improvement of Higher Education Personnel (CAPES) for the scholarship to the student and the forest company for the support during the research.

\section{REFERENCES}

BARNES, R. M. Estudo de movimentos e de tempos: Projeto e medida do trabalho. Americana: Edgard Blucher, 1977. $635 \mathrm{p}$.

CALLEGARI-JACQUES, S. M. Bioestatística: princípios e aplicações. Porto Alegre:Artemed, 2003. 255 p.

CARMO, F. C. A.; FIEDLER, N. C.; MINETTE, L. J.; SOUZA, A. P. de otimização do uso do trator florestal forwarder em função da produtividade, custos e capacidade de carga. Árvore. Viçosa, v. 39, n. 3, p. 561-566, 2015.

CARnEIRO, J. G. A.; FERRAZ, T. M.; SILVA, M. P. S.; BARROSO, D. G. Princípio de desramas e desbastes florestais. Campos dos Goytacazes, RJ: O Coordenador, 2012. 96 p.

CAVIGLIONE, J. H.; BERNARDES KIIHL, L. R.; CARAMORI, P. H. \& OLIVEIRA, D. Cartas climáticas do Estado do Paraná. Londrina: IAPAR, 2000.

GRAYBILL, F. A. Theory and application of the linear model. Belmont: Duxbury Press, 1976. 704 p.

LEITE, E. S.; FERNANDES, H. C.; MINETTE, L. J.; SOUZA, A. P.; LEITE, H. G.; GUEDES, I. L. Modelagem do desempenho da extração de madeira pelo "forwarder". Árvore. Viçosa, v. 38, n. 5, p. 879-887, 2014.

LOPES, E. S.; DINIZ, C. C. C.; SERPE, E. L.; CABRAL, O. M. J. V. Efeito do sortimento da madeira na produtividade e custo do forwarder no desbaste comercial de Pinus taeda. Scientia Forestalis, São Paulo, v. 44, n. 109, p. 57-66, 2016.

FLORESTA, Curitiba, PR, v. 48, n. 2, p. 285-292, abr/jun. 2018.

Rodrigues. C. K. et.al.

ISSN eletrônico 1982-4688

DOI: $10.5380 /$ rf.v48 i2.56195 
LOPES, E. S.; OLIVEIRA, D.; SILVA, P. C.; CHIQUETTO, A. L. Avaliação do desempenho de operadores no treinamento com simulador de realidade virtual forwarder. Ciência Florestal, Santa Maria, v. 20, n. 1, p. 177$186,2010$.

MALINOVSKI, R. A.; MALINOVSKI, R. A.; MALINOVSKI, J. R. YAMAJI, F. M. Análise das variáveis de influência na produtividade das máquinas de colheita de madeira em função das características físicas do terreno, do povoamento e do planejamento operacional florestal. Floresta, Curitiba,v. 36, n. 2, p. 169-182, 2006.

MAZÃO, C.; BROWN, R. O.; ROBERT, R. C. G. Análise da produtividade de um forwarder com o aumento da área da garra de carregamento. Espacios, v.38, n. 11, p. 20-27, 2017.

MIYATA, E. S. Determining fixed and operating costs of logging equipament. Washington: USDA Forest Service, 1980. 16 p. (NC General Technical Report, 55).

NURMINEN, T.; KORPUNEN, H.; UUSITALO, J. Time consumption analysis of the mechanized cut-to-length harvesting system. Silva Fennica, Finland, v. 40, p. 335-363, 2006.

NUUTINEN, Y.; VÄÄTÄINEN, K.; ASIKAINEN, A.; PRINZ, R.; HEINONEN, J. Operational efficiency and damage to sawlogs by feed rollers of the harvester head. Silva Fennica, Finland, v. 44, p. 121-139, 2010.

OLIVEIRA, D.; LOPES, E. S.; FIEDLER, N. C. Avaliação técnica e econômica do Forwarder na extração de toras de pinus. Scientia Forestalis, São Paulo, v. 37, n. 84, p. 525-533, 2009.

SCHENEIDER, P. R.; SCHNEIDER, P. S. P. Introdução ao Manejo Florestal. Santa Maria: FACOS-UFSM, 2008. 566 p.

SEIXAS, F.; CASTRO, G. P. Extração. In: MACHADO, C. C. Colheita florestal. 3.ed. Viçosa: UFV, 2014. p. 106-177.

SPINELLI, R.; NATI, C. A Low-Investment fully mechanised operation for pure selection thinning of pine plantations. Croation Journal of Forest Engineering, v. 2, n. 30, p. 89-97, 2009. 